\title{
Market heal thyself: the challenges of a free market in higher education
}

\author{
Jane Hemsley-Brown PhD (University of Surrey Business School)
}

The market is now accepted as an organizing principle of the world economy and is gradually replacing a number of political extremes ranging from totalitarianism to communism. The market continues to be viewed as way of addressing a wide range of social, industrial and economic issues: improving economic efficiency; greater value for money; enhancing innovation: a more cost effective way of achieving goals; increasing quality and the ability to compete more effectively internationally. These are just a few of the expectations of effective markets, but can the market be expected to compensate for its own shortcomings? Notwithstanding the continuing and emerging downsides to markets worldwide such as the failure of financial and housing markets, the mechanism continues to be viewed as a panacea for economic, social and political challenges in the delivery of education - even to the point of being viewed as the solution to its own failings.

I will begin with a brief introduction to the launch and development of market principles and market mechanisms in higher education, and trace the challenges of markets and marketisation brought about by simultaneous internationalization. Then, I raise questions about the operation of a free market in education as it is poised to become the overriding mechanism for the allocation of resources worldwide. I explore some of the potential damage the market can inflict on higher education, and raise concerns that the achievement of some of the fundamental and core values of higher education are in conflict with the market - 
Hemsley-Brown, J. (2011). Market Heal Thyself: the challenges of a free marketing in higher education. Journal of Marketing for Higher Education, 21, 115-132.

including evidence that markets are known to increase social polarization and reduce equality of access.

\section{The rise and rise of the market}

The dominance of markets is one defining feature of post modernity (Kenway et al. 1993 p.42). Underpinning the move towards enhanced marketisation in higher education is the need for considerable growth in the market. There have been two key drivers of growth. First, government cuts have forced universities to consider alternative sources of income including income from international activities such as foreign student recruitment and partnerships. The second driver has been the process of globalisation, the growth in global trade, communications and interconnectedness (Foskett 2011). The market is becoming so widely accepted in economic and business contexts that issues which emerge through the market's own shortcomings are now viewed as problems which can and should be addressed by governments through the enhancement of the market rather than resorting to other mechanisms.

Despite the rise of public-sector markets, however, higher education continues to be largely provided and funded by governments and all institutions whether public or private are subject to regulations and to the disciplinary systems associated with modernisation (Marginson 1995) regardless of the level of marketisation. One of the characteristics of the UK higher education system is that in the UK there is greater autonomy in the provision of new programmes, selection of students, recruitment and salaries of academic staff compared with France, Germany, Italy and Spain (Agasisti and Catalano 2006). However, (Young 2002) claims that there has not been a reversal of government attitudes per se in recent years, but governments have simply discovered new ways of organizing reform and control. The main 
Hemsley-Brown, J. (2011). Market Heal Thyself: the challenges of a free marketing in higher education. Journal of Marketing for Higher Education, 21, 115-132.

drivers of marketisation include the need to accommodate larger numbers of students without compromising on quality; and determining the extent of the role of the state and the pace of marketisation (Brown 2011).

Although efficient at producing some products and services, however, the free market system often fails to produce effective education (as well as sanitation or law and order) without some form of intervention to compensate for the limitations of markets and this is viewed as justification for government intervention in markets. The limitations of the theory of markets are that higher education 'confers both collective (public) and individual (private) benefits'; there are difficulties in obtaining and disseminating proper information about quality; and the amount of 'product differentiation can be a problem by virtue of the product life cycle' (Brown 2011 p.12).

By seeking to free up markets to gain further benefits from its known strengths governments also place demands on markets to address some of its known weaknesses such as increased social polarisation and inequality of the distribution of resources. The market, in other words is also viewed a mechanism for addressing issues of social and economic inequity, despite the argument that it is the market which contributes to this outcome. The market is required to 'heal thyself'.

I begin by tracing the introduction and development of market principles and market mechanisms in the higher education system (Baldwin and James 2000) and identify the challenges of markets and marketisation. First, I contend that the known downsides of markets are constantly brushed aside by governments, and further freeing up of the market in education is all too often viewed as a solution rather than a consequence of the market's negative characteristics, which is that markets tend to exacerbate social polarisation and 
Hemsley-Brown, J. (2011). Market Heal Thyself: the challenges of a free marketing in higher education. Journal of Marketing for Higher Education, 21, 115-132.

increase inequality. I then examine and then raise questions about the operation of a free market in higher education (HE) as a solution to political and economic change by exploring the conflicts whereby features of the market prevent the achievement of some of the fundamental and core values of higher education, and finally I argue that in the UK the so called quasi-market system of higher education has now moved further towards a free market based on raising income through tuition fees rather than public subsidies and is moving further away from a quasi-market, towards a market that still fails to meet some of the essential requirements for a truly free market required to succeed.

\section{Markets, freedom and constraints}

The market argument is largely based on the seductive concept of freedom - freedom from external control that brings with it reductions in the costs of production and distribution and lower prices based on competition in the marketplace (McMurtry 1997). Freedom is limited in higher education markets on the demand side and the supply side and it is mainly in the context of increasing privatisation brought about by reductions in government funding that universities are experiencing greater 'freedom' - universities have gained the freedom to succeed or fail financially by raising revenue through student fees, research income and enterprise. In particular, markets are often contrasted favourably against command economies 'where both prices and quantities are controlled by the state' (Brown 2011 p.11). A purely free market would require 'autonomous institutions with no regulation on market entry'; there would be 'no regulatory limit on tuition fees and the cost of fees would be met by the users'.

The users would also decide 'what, where and how to study' (Brown 2011 p.12). Reductions in costs to consumers themselves (one of the benefits of markets) remains elusive in higher education, however, as government funding is reduced and students are required to bridge the 
Hemsley-Brown, J. (2011). Market Heal Thyself: the challenges of a free marketing in higher education. Journal of Marketing for Higher Education, 21, 115-132.

funding gap through fee rises (Curtis and Williams 2010). On the demand-side students are also constrained in their choices within the free market by their background and social capital as well as more importantly through their academic credentials. Education is 'an excludable good' i.e. student numbers can be limited by academic selection criteria and tuition fees (Agasisti and Catalano 2006 p.247). On the supply-side universities are constrained by the intervention of highly political legislation and party politics (Curtis and Williams 2010). Despite the rhetoric the market in higher education is still far from 'free'.

The market and the logic of perfectly competitive market functions rather more as an ideological concept (particularly in the US) where it aims to achieve more efficient and equitable allocation of higher education (Young 2002), but in reality despite the bursaries, grants and other incentives for disadvantaged students, the system still favours those with high socio-economic status (SES) (Perna and Titus 2004). This highlights the clashes that exist between equality and excellence as well as the conflicts between academic freedom and accountability. There is increasing tension between universities and governments in many countries in terms of who should pay for higher education in the context of high growth. This includes some advanced countries which have achieved massification or even the postmassification stage of higher education (Arimoto 1997). The more the market is freed up to competition the more the problem of inequity emerges, however, rather than relying on government intervention, the market itself is often expected to reduce such inequalities

\section{Cutbacks and competition}

Limited privatization and extensive marketisation are worldwide phenomena (Kwong 2000). Underlying the movement towards a market model for higher education has been the sustained cutbacks in education since the 1970s. For some years now the justification for 
Hemsley-Brown, J. (2011). Market Heal Thyself: the challenges of a free marketing in higher education. Journal of Marketing for Higher Education, 21, 115-132.

these cutbacks and for the introduction of the market mechanism in higher education has been that is it necessary for universities to compete economically in the international market place (McMurtry 1991) In most countries, marketisation has been viewed as a 'compromise between privatisation, academic autonomy and state control' (Young 2002 p.79) as established leaders throughout the world called for 'freedom from all the shackles of government regulation' (Dill 2003 p.136); (Hemsley-Brown and Oplatka 2006). Even though there was traditionally a resistance to the reduction of education to a resource or a business like any other, over recent decades this resistance has almost disappeared and education is now a commodity, and is promoted in the international market place in competition with other providers (McMurtry 1991)

\section{The concept of marketisation}

In a previous paper with Oplatka (Hemsley-Brown and Oplatka 2006) we pointed out that higher education market is now well established as a global phenomenon, especially in the major-English speaking nations: Canada, the US, Australia and the UK (Binsardi and Ekwulugo 2003) and the literature provides evidence of marketisation and the deregulation of universities in the US (Allen and Shen 1999; Dill 2003), Canada (Kwong 2000; Young 2002), the UK (Middleton 1996; Williams 1997; Gibbs 2001; Taylor 2003), Australia (Baldwin and James 2000) and New Zealand (Ford et al. 1999). However, governments have also turned to deregulatory policies in Japan (Arimoto 1997), Russia (Hare and Lugachev 1999), the Eastern Bloc (Czarniawska and Genell 2002), Holland (Jongbloed 2003), Spain (Mora 1997), Israel (Oplatka 2002), China (Williams et al. 1997; Mok 1999; Mok 2000), Asia (Gray et al. 2003) South Africa (Ivy 2001; Maringe and Foskett 2002) and Zimbabwe (Maringe 2004) (see (Hemsley-Brown and Oplatka 2006). 
Hemsley-Brown, J. (2011). Market Heal Thyself: the challenges of a free marketing in higher education. Journal of Marketing for Higher Education, 21, 115-132.

To improve efficiency and make institutions more adaptable to the changing expectations of the global economy, importing market mechanisms is viewed as a superior means of achieving necessary change due to increasing demand for higher education and reduced public funding (Young 2002). Marketization in education refers to the adoption of free market practices in running universities. These include the business practices of cutting production costs, abandoning courses and programmes not in demand, offering more popular programmes and facilities and advertising to increase brand image, sales and the profit margins: a business language and culture unfamiliar in higher education twenty years ago (Kwong 2000; Young 2002)

The marketing of higher education is set within the broader context of government policy and commissioned reports (e.g. Dearing 1997; Stoops 2004; Spellings 2006) and on-going debates and concerns, for example, funding ((Greenaway and Haynes 2000; Brown 2011; Foskett 2011); issues of social democracy (Ranson 1993); ethnicity (Ishitani 2006) and fears about the McDonaldisation of higher education (Ritzer 2000). (The model's principles of efficiency, calculability, predictability and control (Ritzer 2000) have also been applied to consumption in higher education, and labelled the McUniversity (Parker and Jary 1995)).

\section{The conditions for markets}

According to (Jongbloed 2003) there are eight conditions for a market and all of these conditions tend to facilitate competition between institutions and organisations and place an emphasis on freedom to make decisions. From a providers' point of view they should have: freedom of entry to the marketplace; freedom to specify the product; freedom to use resources; and to determine prices. From a consumer point of view customers should have freedom to choose a provider and the product; have adequate information about the costs and 
Hemsley-Brown, J. (2011). Market Heal Thyself: the challenges of a free marketing in higher education. Journal of Marketing for Higher Education, 21, 115-132.

the quality; should be paying directly, and prices should cover costs (Jongbloed 2003). Although entrance to the undergraduate market is more strictly controlled in many countries, in terms of post graduate higher education evidence of freedom of entry to the market is increasingly apparent and is happening worldwide, particularly in the English speaking countries (Hemsley-Brown and Oplatka 2006). New types of for-profit and non-profit organizations are beginning to provide competition in targeted segments of higher education (Armstrong 2001). These new universities and colleges of higher education have emerged and expanded to meet demand, and they have freedom to select their curriculum and programmes, many offering business and management programmes exclusively because of the high global demand (the London School of Business and Finance based in London, Manchester, Birmingham (UK) as well as Canada and Singapore, is just one example). In recent years the expansion of private provision to meet the demands of overseas students is a further indication that there is relative freedom of entry to the market and freedom to choose what is on offer, for example the University of Kalamoon, Syria set up in 2002. The University of Phoenix, US, which started in 1976, and is now the largest private university in North America (http://www.citytowninfo.com/school-profiles/uph-online, 2010).

In graduate and post graduate markets international applicants have a free choice about provider - although they are individually constrained in their choices by their qualifications. The drive to improve the quality of higher education through the enhancement of market forces in the allocation and delivery of higher education is based on an assumption that students are informed consumers making rational choices of higher education courses and institutions (Baldwin and James 2000). Some authors argue that there are limitations and constraints upon applicants' knowledge and understanding of the higher education system because the product is not visible and the opportunities for repeat purchase are limited 
Hemsley-Brown, J. (2011). Market Heal Thyself: the challenges of a free marketing in higher education. Journal of Marketing for Higher Education, 21, 115-132.

(Brown 2011). However, there is generally more information about universities via the Internet (Klassen 2002) as well as through traditional sources - particularly regarding costs and fees; quality is also communicated and debated through marketing communications and national and world league tables. For post graduate programmes, costs are calculated to cover universities' expenditure and pricing is now closely linked to quality and status - all features of conventional markets. The final criterion for a market - which is that all university students should pay directly and cover costs, has been put in place in the UK with the White Paper on Higher Education funding in England (BIS, 2011) to raise tuition fees to a maximum of $£ 9,000$ a year and withdraw public funding - which effectively privatises university education and shifts higher education from a quasi-market and closer to a free market, although there is still likely to be government intervention in the market - if only to set the upper limit of tuition fees.

(Brown 2011) argues that in a free market funding should be linked to enrolments and absence of externally imposed limits on numbers, however there is considerable variation in terms of funding even within Europe. In the recent changes to tuition fee arrangements in the UK there is an upper limit imposed on the price $(£ 9,000$ for 2012$)$ and there are still government limits on the number of UK and EU undergraduates who can be recruited without penalties. Italy fixes a maximum threshold of the overall tuition fee budget in relation to the public funding total for each institution and in France the state determines the fee for each course of study with variations for different types of courses and disciplines. Higher education in Germany is free but there is a constitutional arrangement whereby fees can be fixed (Agasisti and Catalano 2006). 
Hemsley-Brown, J. (2011). Market Heal Thyself: the challenges of a free marketing in higher education. Journal of Marketing for Higher Education, 21, 115-132.

\section{Downsides to the market in HE}

The main generic disadvantage of the free-market economy is the unequal distribution of wealth (Jowsey 1998). This finding is an important one but has tended to be largely ignored or at least overlooked by the proponents of markets and relates to the price mechanism and the expected outcomes of, in this case, education. The price mechanism tends to fail in public-sector markets because the payment systems are complex, fees can often be paid by others (such as families or employers) and through bursaries, or through loans paid back long after consumption. The benefits of economies of scale fail to result in the expected low prices found in other markets - research is needed to establish in what circumstances university enrolments might be price elastic, but tuition price is negatively related to enrolments (Allen and Shen 1999). This means that one of the major benefits of markets for customers - low prices through mass provision and significant growth - is unlikely to materialize in the higher education market.

The recent plan to raise fees and create a privatised university system in the UK is already attracting criticism because of disregard for social and financial disadvantage but this known downside to markets continues to be under-estimated by governments (Curtis and Williams 2010) and contributes to future inequality of the distribution of wealth. Governments continue to further free-up the market (which raises the costs to students) but simultaneously put pressure on universities to widen access; but the former makes the latter more challenging. The free market is expected to solve the problems of inequity, but inequity is a result of the increasingly free market.

The underlying argument for universities setting high fees is that the price will be a signal of quality: lower fees imply lower quality and therefore a university which claims to offer 
Hemsley-Brown, J. (2011). Market Heal Thyself: the challenges of a free marketing in higher education. Journal of Marketing for Higher Education, 21, 115-132.

excellence will set the highest fees they can justify (Coughlan 2011). It might also be argued that in some instances high prices attract the best qualified applicants on the basis that higher education is a prestige good. One of the attractions towards higher cost higher education provided by some institutions is that visible consumption of expensive products and services is a signal of success and wealth which increase social prestige for the individual. However, there is a downside, despite the requirement to put widen access initiatives and bursaries in place, higher fees result in some students being deterred from applying to university or leaving university early. Fear of debt by those from low incomes families places serious constraints on university choice (Callender and Jackson 2008).

Free market proponents also tend to underestimate the extent of the government interventions needed to provide protection from the weaknesses of the market and to provide services and incentives for those who cannot pay or are unwilling to participate. Even with this provision in place those in the middle and lower income groups are embarking on a life-time of debt whilst those on the lowest incomes could be deterred from applying, despite bursaries and other financial support (Curtis and Williams 2010), further exacerbating inequalities in terms of wealth.

The first step is for governments to intervene for the benefit of those on low incomes, rather than providers themselves being charged with this role. By expecting individual providers to put in place separate schemes and initiatives this creates a complex and confused market for those least-able or willing to track down and make sense of the complex eligibility criteria. Typically, governments are creating a more competitive market which encourages universities to charge the highest prices the market can stand in order to reduce government's financial contribution to higher education, but at the same time universities have to find ways 
Hemsley-Brown, J. (2011). Market Heal Thyself: the challenges of a free marketing in higher education. Journal of Marketing for Higher Education, 21, 115-132.

to ensure that those who cannot pay are not excluded. While some governments (such as in the UK) provide some grants for low income families, higher education is mostly funded by loans that have to be paid back. This is also true in the USA where the interest accrues immediately and students start paying back the loan shortly after leaving college. Not only are providers in these countries expected to find ways of being inclusive towards disadvantaged students but the service itself must be the same. This is the equivalent of expecting the Dorchester Hotel in London to offer the same quality of suite and services for the same price across their business. However, commercial enterprises in a competitive market do not operate this way, typically segmentation occurs, and to extend the metaphor, the Dorchester Hotel, will offer a range of suites at different prices from $£ 4,750$ to a mere $£ 250$ for a room, as a more affordable product and service to widen their customer base. (This is not a recommendation for universities to ponder - it is an observation of how the free market operates in the commercial sector to accommodate different market segments.)

Most other service businesses, especially prestigious services, offer a reduced service to those who pay less. The services and products offered to meet different markets vary in price considerably but it reduces prestige to offer services at prices that are too low. Universities, however, are committed to offering the same high quality tuition to everyone regardless of their ability to pay but this approach is unlikely to be sustainable or affordable in a free market system in the long term. In order to maintain service levels, subsidies have to come from elsewhere such as through government (although there is considerable pressure on universities to seek funding from other sources including industry). It is counter intuitive to expect a provider to offer an identical service at different price points at the same time on an on-going basis, because those having to pay more will question the rationale - particularly as the payback period may run for years. Higher paying customers will perceive that they and 
Hemsley-Brown, J. (2011). Market Heal Thyself: the challenges of a free marketing in higher education. Journal of Marketing for Higher Education, 21, 115-132.

their families are subsidising those who pay less. Whilst it is acceptable - if not expected for governments to pay for those who cannot pay, it is a substantial and contentious step to expect those who can pay, to more directly subsidise those who cannot. This is a tough challenge but to expect a free market in higher education to buck the trend compared with markets in other contexts is stacking the dice against them and setting higher education up to fail in the market.

Critics of the free market in higher education argue that it fails to deliver low cost for everyone, despite fierce competition in the marketplace (McMurtry 1997). The expectation (by proponents of markets) is that variations in price, quality and value offered by higher education providers would drive down prices, and push some consumers towards a more rational decision process to get the best value for money. However, whilst some consumers would employ this approach, for choosing universities, the cost of providing a one-size-fitsall experience for the same price for everyone in the institution, makes it difficult to reduce costs to the student, and increasingly likely that the university sector will be divided into high and low prestige institutions. Therefore, rather than providing low cost higher education for everyone, the free market mechanism results in a highly segmented system where the most advantaged can afford to attend the high priced prestigious institutions and the least advantaged can only attend the lower-priced lower-status institutions. Despite pressure for the higher education system to be more inclusive, a free market approach exacerbates the inequalities that consumers bring to the market.

At the outset the essential requirement for putting support in place for the less advantaged has not always been fully recognised in higher education: the sentiments that lead to this commitment have been far stronger than the practice. Who pays the subsidy - government or 
Hemsley-Brown, J. (2011). Market Heal Thyself: the challenges of a free marketing in higher education. Journal of Marketing for Higher Education, 21, 115-132.

the provider? The recent enhancement of the free market in the UK, through the introduction of tuition fees imposes demands on providers to ensure that those who are least able to pay the fees are given full access to programmes alongside those who are able to pay. This is the equivalent of the state expecting the Dorchester Hotel to put in place a system that enables the poorest to gain access to the best suite in the hotel, that is: the providers of excellence are given the go-ahead to charge high prices in a free market as long as the poorest are not excluded. Moreover, as I have emphasised - it is the market itself that is expected to address this contradiction.

There is considerable research that supports these concerns in terms of higher education. Research in the United States concludes that first generation students and those on lower incomes are less likely to complete their degrees (Ishitani 2006). This study found that student loans are negatively associated with student progression rates whilst grants (even in conjunction with loans) reduced attrition rates (Ishitani 2006) but countries continue to put tuition fee structures in place. The commitment to student progression and student access is often strong not only within the sector but more widely, but this has not always resulted in legislation and practice that match the rhetoric.

In circumstances where the market mechanism fails government intervention is needed, because higher education has positive externalities: benefits are enjoyed by the greater public (Agasisti and Catalano 2006). Begg et al. (1991) identify four reasons why government intervention in the market is needed: externalities; information-related problems; monopoly and market power, due to barriers to entry in the market (Jongbloed 2003). University education produces substantial private benefits in terms of higher income and social status for the individual (Agasisti and Catalano 2006) and it is this private benefit that is the basis of the 
Hemsley-Brown, J. (2011). Market Heal Thyself: the challenges of a free marketing in higher education. Journal of Marketing for Higher Education, 21, 115-132.

argument that students should contribute significantly to the costs of their own higher education. Universities, however, produce both private goods (i.e. education, employability) and public goods (e.g. research outputs; a better educated workforce; and social benefits for society). Students may not be fully aware of the externalities or spill-over benefits such as investment in education and in society as a whole, and therefore it has always been thought reasonable that government should contribute towards the cost of such societal benefits. Through increasing marketisation of higher education, however, it could reached a point whereby governments do not expect to provide any financial support for higher education and the public goods associated with it - therefore the public benefits are likely to decrease as a result of the more selfish choices of student-investors who focus on private benefits.

In an ideal market the logic suggests that higher education courses that are of value to employers would result in higher wages and greater employability, leading to greater student demand in those subjects. However, there are problems in terms of student-investors gaining access to the information they need to make good investment decisions: there is no mechanism for employers to send signals directly to students about the value they place on particular courses. There are also problems because of the time-lag between applying to university and applying for a job - job markets can change substantially, and economies in different countries can change. These changes are even more rapid and extensive in the globalised economy: students can apply to study in the UK or the US, for example, in order to secure a job following graduation, but by the end of their course programme the employment situation and the visa arrangements can mean this outcome is no longer feasible.

Employability data are also only published at university level rather than on a department basis, and information about types of jobs or salaries is not included. The complexity of 
Hemsley-Brown, J. (2011). Market Heal Thyself: the challenges of a free marketing in higher education. Journal of Marketing for Higher Education, 21, 115-132.

graduate employability data is masked in the way league table information is presented. Students would benefit from much clearer market signals, which would include a better picture of where the graduates from a particular course find work, and how much they earn (Lambert 2003). Nonetheless, students are rarely counselled on the basis of employability when they choose universities and degree programmes by those who contribute to university choice. Benefits for society as a whole have no place in the choice process of students who are operating in a higher education market where the customer pays for his or her own consumption.

Concerns are also often raised about access to information in markets especially to ensure applicants are able to make informed choices - although in recent years expansion in information technology through the Internet has increased access to information about universities (Klassen 2002) and facilitated rational choice. Government intervention may also be justified to prevent monopolies and to reduce the barriers so that new providers can emerge. The threat of monopolies is currently limited, but concerns about new universities world-wide raise issues to do with the measurement of quality. The high cost of research universities also presents a tremendous barrier to entry for any new competitors seeking to compete on the same basis (Armstrong 2001). Most new universities appearing rapidly on the scene are seeking to secure a share in the rising numbers of international students in subject disciplines that are increasingly popular such as computing and business, rather than seeking funds for high quality research. From the student perspective there are still few situations where the full costs are paid via bursaries or scholarships (Jongbloed 2003), students still tend to contribute towards the cost of their higher education to some extent. 
Hemsley-Brown, J. (2011). Market Heal Thyself: the challenges of a free marketing in higher education. Journal of Marketing for Higher Education, 21, 115-132.

Marketisation, or the private administration of education, may affect the nature of education, but it does not threaten government domination of education. Governments are reluctant to relinquish their control of education and the public is reluctant to give up their entitlement to education (Kwong 2000 p.91). Therefore, despite the rhetoric of the free market in higher education there are conflicts in terms of what the market can deliver. The goal in the marketplace is to increase profit for the suppliers whereas that of the public services is to benefit the collective. A firm's performance can be measured by the amount of money made whereas public services, like HE, cannot always be calibrated in financial or quantitative terms (Kwong 2000 p.92). Increased competition will provide more options for students, and students will respond by maximizing benefits to themselves as individuals. The sum of these individual (selfish) decisions will not always lead to global changes that are positive (Armstrong 2001) or contribute the good of society as a whole. All institutions whether public or private are subject to regulation and to the disciplinary systems associated with modernisation (Marginson 1995). An important means of how governments control, interact with, and shape markets is through regulation. Regulatory measures exist in higher education largely to control the behaviour of sellers in the market, and are concerned largely with the prices of various services provided by institutions. One of the major forms of regulation concerns tuition fees, and has been used by various governments to control the forces of supply and demand for undergraduate education (Young 2002).

Raising tuition fees may bring more income to universities, but additional fees may discourage the disadvantaged from attending (Kwong 2000). The quasi-market of education is not a level playing field. These policies may benefit some students but not others, especially the disadvantaged ones (Kwong 2000). 
Hemsley-Brown, J. (2011). Market Heal Thyself: the challenges of a free marketing in higher education. Journal of Marketing for Higher Education, 21, 115-132.

\section{Conflicts of marketisation}

The underlying conflicts between the market and education were voiced in the 1990s when the market was viewed as a solution to cutbacks in public services and reductions in funding (McMurtry 1991). The disadvantages of the market when applied to higher education, despite many advantages for students and for governments, is the potential for producing policy conflict and confusion based on: opposing goals; opposing motivations; the problem of price and value; the notion of excellence; whether government-control increases or decreases; and serious concerns about the social polarisation effects of markets. I will further explore these conflicts below. McMurtry (1991), for example, set out some key differences between the principles of the capitalist market and of education in terms of the processes and the goals of education and the market, which he argues are contradictory in significant respects.

First markets and education have opposing goals: private and corporate organisations seek principally to maximise profits rather than to advance and disseminate shared knowledge as universities are or were, expected to focus on. Universities in a free market are forced to maximise income both from research and teaching and may be forced into closure or a merger as a result of cuts in public funding (BBC News 2010). Decreasing government funding for both research and teaching, and increasing pressure to maximise income is changing the nature and focus of higher education from a process of learning to a product (Scott 1997) which is delivered in the context of consumerism to meet the needs of industry (Gumport 2000).

Secondly, business and higher education have opposing motivations because satisfaction of the wants of customers is the overriding motivation of the market for both buyers and sellers. For example, one problem is that what a student wants to consume or buy can divert students 
Hemsley-Brown, J. (2011). Market Heal Thyself: the challenges of a free marketing in higher education. Journal of Marketing for Higher Education, 21, 115-132.

away from their education and what is expected of them. Those who have the greatest motivation to study are not necessarily those with the greatest resources to pay for studying which raises serious issue about equal access.

Thirdly, (McMurtry 1991) argues that the method of the market is to buy and sell goods and services for whatever price the market can stand. This is the opposite in the case of education where the goods have to be earned through autonomous effort and achievement. This difference in the methods of markets and education means that as commodities depreciate in value depending on their use, for education which cannot be consumed, as such the value increases with participation or use. As the proportion of educated people expands, there is a decline in the returns associated with acquiring education (Marginson 1995). Though these concerns are serious - for example equal access - concerns have been raised about the devaluing of education with the increase in participation. But fundamentally raising the level of education each individual achieves is surely a positive outcome for the individual and society despite the devaluing of the qualifications.

Fourthly, despite the claims universities make about excellence in a market driven system measures of excellence in education are different from those of the market. This discourse constitutes what higher education is, its identity is promoted by arguments that higher education must somehow be relevant - and signals a shift towards outcomes rather than process. What was once personal economic benefit and the development of the individual contributing towards future career needs (Robbins 1963) is transferred to the needs and demands of the economy. What constitutes excellence in the market can also be different for education. The best product on the market is one which is the most problem free for the purchaser, delivered ready made for instant use, and that's often why the education system in 
Hemsley-Brown, J. (2011). Market Heal Thyself: the challenges of a free marketing in higher education. Journal of Marketing for Higher Education, 21, 115-132.

a free market faces problems. The best education cannot be experienced by anyone except the learner and is never ready-made or even problem-free in terms of the learning and achievement. There are elements of the delivery that universities now try to make problem free but the achievement, and reduction in failure is problematic if education is to be able to claim excellence. Students are expected to become more independent and this is opposite to the problem-free, ready-made notion of an excellent product (McMurtry 1991). This has tended to lead to a continuing focus on the service delivery aspects of HE (Brookes 2003; Petruzzellis et al. 2006; Prugsamatz et al. 2007; Angell et al. 2008; Brown et al. 2009), where students focus on the lecture notes, e-learning access and feedback issues rather than their personal development and achievements. The emphasis in previous decades on using the market to enhance quality and competition, however, has also shifted. The focus has become the issue of who should pay for higher education because a true market relies on consumers who are paying for their own consumption.

Fifth, the introduction of market mechanisms does not appear to reduce government control despite the notion of 'freedom' that underpins the market, however, government intervention seems to restrict prices but not offer incentives or support for those who are least likely to study in higher education - this is now the responsibility of the providers. What has taken place is a change in the nature of the inducements the state offers to encourage universities to adopt government identified priorities and activities. Competition for example, whilst improving quality and diversity of provision, also has winners and losers and society has to find ways of helping the losers particularly in the case of public-sector provision (Beardshaw et al. 1998). This argument seeks to justify government intervention in markets because of the need to provide adequate support and provision for the disadvantaged - however, as the 
Hemsley-Brown, J. (2011). Market Heal Thyself: the challenges of a free marketing in higher education. Journal of Marketing for Higher Education, 21, 115-132.

market becomes more dominant governments begin to expect the providers themselves to take on the challenge of addressing the downsides the new freer market will bring.

One of the key arguments of this Editorial is to highlight that governments impose markets on the public sector, progressively free up the markets and shift the responsibility for addressing the downsides of the system to the providers. The seriousness of this downside to markets is rarely fully acknowledged and the market itself cannot fully address its own weaknesses (even though universities continue to battle to address the problem). Ignoring this effect results in a serious conflict in terms of what the market itself can, and is expected to achieve in the delivery of public sector services. Students in different age, social class and income groups vary in terms of the reasons for their choices in higher education and this further contributes towards social polarisation and inequality of access.

Assumptions about the so-called rationality of student-consumers also have an impact because only some university applicants are making economic-rational decisions and this contribute towards polarisation in the market place. Students who choose their course with consideration for their future careers tend to be those who are older, in the lowestparticipation social groups, have lower entry scores, attend lower-ranked universities and are studying courses in law, mass communication and education (Hemsley-Brown and Kolsaker 2008). Students who are younger (aged 18-25) tend to have higher entry scores attend higher-ranked universities, are from high participation groups, and are more likely to be studying creative arts, history, philosophy, languages, veterinary science, agriculture, or physical sciences. These students are also more likely to study a subject for its own sake rather than because of the economic benefits and future employability (Hemsley-Brown and Kolsaker 2008). 
Hemsley-Brown, J. (2011). Market Heal Thyself: the challenges of a free marketing in higher education. Journal of Marketing for Higher Education, 21, 115-132.

Finally therefore, since the very beginning of the enhancement of the free market in higher education, there have been concerns raised about the social polarisation effect of the market. Although markets are seductive because they promote autonomy enabling all participants to make decisions for themselves - markets are also myopic, offering people what they want rather than what society might identify as a need. The market, therefore, masks social bias it reproduces the inequalities which consumers bring to the market place (Ranson 1993). There is considerable evidence of this effect in markets whereby people from higher socioeconomic groups simply consume different products and services compared with the less well off: those with reduced social capital. Prestige brands such as high status institutions, in addition to the barrier of high prices, target those with high qualifications, high social capital and high social status and those who fall below that profile are far less likely to consider applying to that institution: that is how market segmentation works in a commercial setting. Private businesses, however, unlike public-sector services, are not put under pressure to try and widen their target audience unless it proves to be profitable. Thus these businesses continue to provide services only to an elite group whilst other businesses target a larger population of those with middle and lower incomes and middle and lower social status. The market is, therefore, a crude mechanism for social selection and reinforces the pre-existing social class order of wealth and privileged (Ranson 1993).

\section{Counter-arguments}

Despite these persuasive arguments there are authors who make a good case against these views. (Tooley 1995) argues that social class polarisation was not eliminated under a planned system for example in pre-Thatcher Britain there was no real optimism to suggest that social class inequalities were significantly lower and in countries with planned 
Hemsley-Brown, J. (2011). Market Heal Thyself: the challenges of a free marketing in higher education. Journal of Marketing for Higher Education, 21, 115-132.

economies there is clear evidence of deprivation, poverty and poor education. To some extent, in a market the disadvantaged have a voice through choice more so than they might under a planned system (Tooley 1995) (although this does not justify the barriers to access to higher education which emerge under the market system).

There is also a counter-argument to this - that it is growth in the economy that leads to social polarisation rather than markets: as the economy improves, so social segregation score increases and vice versa (Noden 2002). Market forces alone therefore, may not lead, necessarily, to the levels of increased social stratification that some authors have claimed (Noden 2002). Further, (Ranson 1993) considers markets and democracy to be in opposition but (Tooley 1995) challenges this. He points out that the market keeps producers 'on their toes' and hence satisfying demand; where markets are not allowed to operate chronic shortages emerge as in the case of the former Soviet Union for example. Providers can be complacent - arrogant even - without market demand. Tooley (1995) also criticises Ranson's (1993) claim that under market system hierarchies develop resulting in some types of provision being considered prestigious and exclusive and therefore they exclude as well as include. But - he goes on to argue - hierarchies of this type are not exclusive to market systems, hierarchies also developed very strongly under a more planned system where access was much more limited (often) to groups who subscribed to political parties or found favour through other connections. In the Soviet Union for example there were still hierarchies and prestigious routes and institutions, they were controlled by government and the state - but they still emerged.

On balance it is therefore surprising that there has been remarkably little resistance within the higher education sector (in England particularly) against decades of government policies that 
Hemsley-Brown, J. (2011). Market Heal Thyself: the challenges of a free marketing in higher education. Journal of Marketing for Higher Education, 21, 115-132.

seek to enhance the market, strengthen competition between universities and promote consumer sovereignty, with the goal of improving efficiency and quality - 'that virtuous ideal glowing at the core of micro-economic reform in higher education' (Marginson 1995 p.5).

Creating a mass education system that retains the notion of prestige, and operating a market system that seeks to widen participation among those who do not traditionally participate because of socio-economic factors - is a challenge, especially at low cost to the consumer. Both the market and government intervention are needed to achieve this for the benefit of those in higher education and those who are reluctant to participate - particularly where there are financial barriers. The effective marketing of higher education is one of the ways of achieving this delicate balance, where some form of higher education is available to all on every street. Nevertheless where a prestige brand is highly attractive to those who can least afford the luxury as well as those who can, conflict is likely to ensue based on notions of fairness and equity as higher education begins to move towards not just McDonaldisation but simultaneous the Louis Vuittonisation. Given that higher education is 'baggage' that an individual cannot simply replace by walking into a high-street store, the outcome of a free (unregulated) higher education market could be long-term social dissatisfaction and mistrust of the social good of higher education.

Reference List 
Hemsley-Brown, J. (2011). Market Heal Thyself: the challenges of a free marketing in higher education. Journal of Marketing for Higher Education, 21, 115-132.

Agasisti, T., and Catalano, G. (2006). Governance models of university systems - towards quasi-markets? Tendencies and perspectives:: A European comparison. Journal of Higher Education Policy and Management, 28(3), 245-262.

Allen, R. F., and Shen, J. (1999). Some evidence of the character of competition among higher education institutions. Economics of Education Review, 18, 465-470.

Angell, R. J., Heffernan, T. W., and Megicks, P. (2008). Service Quality in Post Graduate Education. Quality Assurance in Education, 16(3), 236-254.

Arimoto, A. (1997). Market and Higher Education in Japan. Higher Education Policy, 10(34), 199-210.

Armstrong, L. (2001). A new Game: competitive higher education. Information, Communication \& Society, 4(4), 479-506.

Baldwin, G., and James, R. (2000). The Market in Australian Higher Education and the Concept of Student as Informed Consumer. Journal of Higher Education Policy and Management, 22(2), 139-148.

BBC News (2010). Budget cuts will lead to university closures. BBC News, News Education \& Family, Available at: http://www.bbc.co.uk/news/education$\underline{10881360((2 / 12 / 2010))}$.

Beardshaw, J., Brewster, D., Cormack, P., and Ross, A. (1998). Economics: A student's guide. Addison Wesley Longman Limited, Harlow. 
Hemsley-Brown, J. (2011). Market Heal Thyself: the challenges of a free marketing in higher education. Journal of Marketing for Higher Education, 21, 115-132.

Begg, D., Fisher, S., and Dornbusch, R. (1991). Economics. McGraw Hill, London.

Binsardi, A., and Ekwulugo, F. (2003). International Marketing of British Education: research on the students' perception and the UK market penetration. Marketing Intelligence \& Planning, 21(5), 318-327. 
Hemsley-Brown, J. (2011). Market Heal Thyself: the challenges of a free marketing in higher education. Journal of Marketing for Higher Education, 21, 115-132.

BIS (Department for Business Innovation and Skills) (2011) White Paper on Higher Education, Available at: http://discuss.bis.gov.uk/hereform/white-paper/ (accessed, July $6^{\text {th }}$ 2011)

Brookes, M. (2003). Higher Education: marketing in a quasi-commercial service industry. International Journal of Non-Profit and Voluntary Sector Marketing, 8(2), 14651520.

Brown, C., Varley, P., and Pal, J. (2009). University course selection and services marketing. Marketing Intelligence \& Planning, 27(3), 310-325.

Brown, R. (2011). "The march of the market." The Marketisation of Higher Educatioin and the Student as Consumer, M. Molesworth, Scullion R., and E. Nixon, eds., Routledge, Abingdon, 11-24.

Callender, C., and Jackson, J. (2008). Does the fear of debt constrain choice of university and subject of study? Studies in Higher Education, 33(4), 405-429.

CTI (City Town Information) (2010) Available online at: http://www.citytowninfo.com/school-profiles/uph-online (Accessed 17/10/2011)

Coughlan, S. (2011). Most degrees will cost $£ 9,000$, predicts student leader. BBC News, 25th January 2011. Available online at: http://www.bbc.co.uk/news/education-12266765 (accessed 17/10/2011).

Curtis, P., and Williams, R. (2010). Nick Clegg claims fees debate could deter poor from applying to university. The Guardian, 30th(November). Available online at: 
Hemsley-Brown, J. (2011). Market Heal Thyself: the challenges of a free marketing in higher education. Journal of Marketing for Higher Education, 21, 115-132.

http://www.guardian.co.uk/politics/2010/nov/30/nick-clegg-tuition-fees-protests (accessed 17/10/2011)

Czarniawska, B., and Genell, K. (2002). Gone shopping? Universities on their way to the market. Scandinavian Journal of Management, 18(4), 455-475.

Dearing, R. (1997). Higher Education in a Learning Society: The National Committee of Inquiry into Higher Education. HMSO, London.

Dill, D. D. (2003). Allowing the Market to Rule: The case of the United States. Higher Education Quarterly, 57(2), 136-157.

Ford, J. B., Joseph, M., and Joseph, B. (1999). Importance performance analysis as a strategic tool for service marketers: the case of service quality perceptions of business students in New Zealand and the USA. The Journal of Services Marketing, 13(2), 171-186.

Foskett, N. H. (2011). "Markets, government, funding and the marketisation of UK higher education." The Marketisation of Higher Education and the Student Consumer, M. Molesworth, Scullion R., and E. Nixon, eds., Routledge, Abingdon, 25-38.

Gibbs, P. (2001). Higher Education as a Market: a problem or a solution? Studies in Higher Education, 26(1), 85-94.

Gray, B. J., Fam, K. S., and Llanes, V. A. (2003). Cross cultural values and the positioning of international education brands. Journal of Product and Brand Management, 12(2), 108-119.

Greenaway, D., and Haynes, M. (2000). Funding Universities to meet National and International Challenges. University of Nottingham, Nottingham. 
Hemsley-Brown, J. (2011). Market Heal Thyself: the challenges of a free marketing in higher education. Journal of Marketing for Higher Education, 21, 115-132.

Gumport, P. (2000). Academic Re-structuring: organisational change and institutional imperatives. Higher Education, 39, 67-91.

Hare, P., and Lugachev, M. (1999). Higher Education in transition to a market economy: two case studies. Europe-Asia Studies, 51(1), 101-122.

Hemsley-Brown, J., and Kolsaker, A. (2008). Higher Expectations: unique insight into the students verdict on admissions, recruitment, marketing and fees. The Opinion Panel, London.

Hemsley-Brown, J., and Oplatka, I. (2006). Universities in a competitive global marketplace: a systematic review of the literature on higher education marketing. International Journal of Public Sector Management, 19(4), 316-338.

Ishitani, T. T. (2006). Studying Attrition and Degree Completion Behavior among FirstGeneration College Students in the United States. Journal of Higher Education, 77(5), $861-885$

Ivy, J. (2001). Higher Education institution image: a correspondence analysis approach. The International Journal of Educational Management, 15(6), 276-282.

Jongbloed, B. (2003). Marketisation in Higher Education, Clarke's Triangle and the Essential Ingredients of Markets. Higher Education Quarterly, 57(2), 110-135.

Jowsey, E. (1998). 100 Essay Plans for Economics. Oxford University Press, Oxford.

Kenway, J., Bigum, C., and Fitzclarence, L. (1993). Marketing education in the postmodern age. Journal of Education Policy, 8(2), 105-122. 
Hemsley-Brown, J. (2011). Market Heal Thyself: the challenges of a free marketing in higher education. Journal of Marketing for Higher Education, 21, 115-132.

Klassen, M. (2002). Relationship Marketing on the Internet: the case of top-and lower-ranked universities and colleges. Journal of Retailing and Consumer Services, 9, 81-85.

Kwong, J. (2000). Introduction: marketisation and privatisation in education. International Journal of Educational Development, 20, 87-92.

Lambert, R. (2003). Lambert Review of Business-University Collaboration. HMSO, London.

Marginson, S. (1995). Markets in Education: A theoretical note. Australian Journal of Education, 39(3), 294-312.

Maringe, F. (2004). Vice chancellor's perceptions of university marketing: a view from universities in a developing country. Higher Education Review, 36(2), 53-68.

Maringe, F., and Foskett, N. H. (2002). Marketing university education: the South African experience. Higher Education Review, 34(3), 35-51.

McMurtry, J. (1991). Education and the Market Model. Journal of Philosophy of Education, 25(2), 209-217.

McMurtry, J. (1997). The Contradictions of Free Market Doctrine: is there a solution? Journal of Business Ethics, 16, 645-662.

Middleton, C. (1996). Models of state and market in the 'modernisation of higher education. British Journal of Sociology of Education, 21(4), 537-554.

Mok, K. H. (1999). Education and the market place in Hong Kong and Mainland China. Higher Education, 37(2), 133-158. 
Hemsley-Brown, J. (2011). Market Heal Thyself: the challenges of a free marketing in higher education. Journal of Marketing for Higher Education, 21, 115-132.

Mok, K. H. (2000). Marketising higher education in post-Mao China. International Journal of Educational Development, 20, 109-126.

Mora, J. G. (1997). Market trends in Spanish higher education. Higher Education Policy, 10(3/4), 187-198.

Noden, P. (2002). Education Markets and Social Polarisation: back to square one? Research Papers in Education, 17(4), 409-415.

Oplatka, I. (2002). Implicit contradictions in public messages of 'low-stratified' HE institutions: the case of Israeli teacher training colleges. The International Journal of Educational Management, 16(5), 248-256.

Parker, M., and Jary, D. (1995). The McUniversity: Organization, Management and Academic Subjectivity. Organization, 2(2), 319-338.

Perna, L. W., and Titus, M. A. (2004). Understanding Differences in the Choice of College Attended: The Role of State Public Policies. The Review of Higher Education, 27(4), $501-525$

Petruzzellis, L., D'Uggento, A. M., and Romanazzi, S. (2006). Student satisfaction and quality of service in Italian universities. Managing Service Quality, 16(4), 349-364.

Prugsamatz, S., Heaney, J. G., and Alpert, F. (2007). Measuring and Investigating Pretrial Multi-Expectations of Service Quality Within the Higher Education Context. Journal of Marketing for Higher Education, 17(1), 17-47.

Ranson, S. (1993). Markets or Democracy for Education. Journal of Educational Studies, XXXXI(4), 333-349. 
Hemsley-Brown, J. (2011). Market Heal Thyself: the challenges of a free marketing in higher education. Journal of Marketing for Higher Education, 21, 115-132.

Ritzer, G. (2000). The McDonaldization of Society. Sage, California.

Robbins, L. L. (1963). Higher Education: A Report of the Committee appointed by the Prime Minister. HMSO, London.

Scott, P. (1997). "The Crisis of Knowledge and the Massification of Higher Education." Higher Education Knowledge Crisis, R.Barnett, and A.Griffin, eds., Cassell, London.

Spellings, M. (2006). A Test of Leadership: Charting the future of US Higher Education. Department of Education, Washington.

Stoops, N. (2004). Educational Attainment in the United States: 2003, Current population reports. Census Bureau.

Taylor, J. (2003). Institutional diversity in UK Higher Education: policy and outcomes since the end of the binary divide. Higher Education Quarterly, 57(3), 266-293.

Tooley, J. (1995). Markets or Democracy for Education? A reply to Stewart Ranson. British Journal of Educational Studies, XXXXIII(1), 21-32.

Williams, G. (1997). The market route to mass higher education: British experience 19791996. Higher Education Policy, 10(3/4), 275-289.

Williams, G., Liu, S. S., and Shi, Q. (1997). Marketisation of higher education in the People's Republic of China. Higher Education Policy, 10(2), 151-157.

Young, S. (2002). The use of market mechanisms in higher education finance and state control: Ontario considered. The Canadian Journal of Higher Education, xxxii(2), 79102. 
Hemsley-Brown, J. (2011). Market Heal Thyself: the challenges of a free marketing in higher education. Journal of Marketing for Higher Education, 21, 115-132. 